\title{
Beard and Holmes on Constitutional Adjudication
}

\section{Citation}

Adrian Vermeule, Beard and Holmes on Constitutional Adjudication, 29 Const. Comment. 457 (2014).

\section{Permanent link}

http://nrs.harvard.edu/urn-3:HUL.InstRepos:16162448

\section{Terms of Use}

This article was downloaded from Harvard University's DASH repository, and is made available under the terms and conditions applicable to Open Access Policy Articles, as set forth at http:// nrs.harvard.edu/urn-3:HUL.InstRepos:dash.current.terms-of-use\#OAP

\section{Share Your Story}

The Harvard community has made this article openly available.

Please share how this access benefits you. Submit a story.

Accessibility 
Forthcoming, CONSTITUTIONAL COMMENTARY

\title{
Beard and Holmes on Constitutional Adjudication
}

\author{
Adrian Vermeule
}

My title is somewhat misleading, because Beard said little about constitutional adjudication, ${ }^{1}$ while Holmes thought little of Beard's most famous book. But I hope it will prove illuminating to wire a connection between these two thinkers. A century ago, Beard set us a puzzle to which Holmes gave us an answer. Not necessarily the only answer, and perhaps not even the right answer. But at least it is coherent, and that is not to be sneered at in constitutional theory. Let me explain.

Charles Beard's 1913 book, An Economic Interpretation of the Constitution, structured a whole field of historical inquiry into the founding, for a generation at least. Does Beardian scholarship have any utility for public law adjudication, and if so, what sort of utility does it have? By "Beardian scholarship" I do not mean just Beard's own book of 1913, which has less and less to offer judges today, as the founding era recedes. (The same point applies to more recent public choice scholarship on the framing era, such as Robert McGuire's book on the political determinants of the framers' behavior. ${ }^{2}$ ) Rather, I mean scholarship in a broader tradition or style that Beard initiated scholarship from an external perspective that attempts to understand and describe the actual motives of constitutional rulemakers, as opposed to their idealized motives, or the public-regarding rhetoric that may accompany their actions and choices. That definition encompasses any work in political economy or positive political theory that attempts to explain the genesis of constitutional rules, unwritten constitutional conventions, and major quasi-constitutional statutes. Examples in the last category include studies on the political origins of the Administrative Procedure $\mathrm{Act}^{3}$ and the Civil Rights Act of $1964 .^{4}$

\footnotetext{
* John H. Watson Professor of Law, Harvard Law School. Presented at the conference on CHARLES A. BEARD, AN ECONOMIC INTERPRETATION OF THE CONSTITUTION OF THE UNITED STATES (1913), University of Virginia Law School, October 24-25, 2013. For helpful comments, thanks to Hank Chambers and the other conference participants, and to Heidi Kitrosser, Sai Prakash, Fred Schauer and Cass Sunstein. Thanks to Rachel Siegel for excellent research assistance.

${ }^{1}$ Beyond defending constitutional judicial review itself as consistent with the original understanding. See Charles A. Beard, The Supreme Court and the Constitution (1912).

${ }^{2}$ Robert A. McGuire, To Form a More Perfect Union: A New Economic Interpretation of the UNiTED STATES CONSTITUTION (2003).

${ }^{3}$ Mathew D. McCubbins et al., Positive and Normative Models of Procedural Rights: An Integrative Approach to Administrative Procedures, 6 J.L. ECON \& ORG. 307 (1990).

${ }^{4}$ Daniel B. Rodriguez \& Barry R. Weingast, The Positive Political Theory of Legislative History: New Perspectives on the 1964 Civil Rights Act and Its Interpretation, 151 U. PA. L. REV. 1417 (2002-2003).
} 
This is really just an example of a larger methodological problem: what is the connection, if any, between the external perspective of the historian or political scientist and the internal perspective of lawyers and judges? ${ }^{5}$ That is Beard's puzzle; Beard challenges us either to reconcile our external and internal perspectives on constitutionalism, or else conceivably to declare them irreconcilable.

I will begin by showing that standard approaches to constitutional adjudication originalism $^{6}$ and Dworkinian moralism ${ }^{7}-$ are resolutely internal and thus have little use for the external standpoint of Beardian scholarship. I will then describe a strategy of reconciliation offered by Justice Holmes, one that connects external and internal perspectives by means of a nonideal theory of constitutional judging. There is some irony here, for Holmes himself was critical of Beard in correspondence. Yet Holmes was more Beardian than he knew; once we understand Holmes' implicit theory of judging, it naturally creates a role for Beardian scholarship.

In my view, Holmes offers a nonideal theory of judging under political constraints; the theory holds that the rational judge chooses the course of action that, at lowest possible cost, adjusts constitutional law and policy to match "the actual equilibrium of force in the community - that is, conformity to the wishes of the dominant power[]." In this framework, Beardian scholarship offers external analysis of the shape and force of the political constraints that the Holmesian judge should take into account when making constitutional law. External Beardian scholarship, in other words, helps to delineate the feasible political options or possibilities for constitutional law ${ }^{9}$, a critical datum from the internal but nonideal perspective of the Holmesian judge. (Beardian scholarship is not the only source of insight into constitutional possibilities, of course; the Holmesian judge faces the question whether to consult materials like public opinion polls, a question I touch upon later).

It is a separate question, of course, whether Holmes's theory is a good one. I do not at all mean to address that question, or to defend Holmes's theory on its merits. I aim to show only that there exists a prominent strand of American theory about judging -- and by definition any theory held by Holmes is prominent -- that is coherent and that allows us to internalize Beardian scholarship within the legal enterprise, should we want to do so.

\footnotetext{
${ }^{5}$ For earlier efforts on this nagging topic, see Adrian Vermeule, Self-Defeating Proposals: Ackerman on Emergency Powers, 75 Fordham L. Rev. 631 (2006); Adrian Vermeule, Connecting Positive and Normative Legal Theory, 10 U. PA. J. Const. L. 387 (2007-2008); Eric A. Posner \& Adrian Vermeule, Inside or Outside the System?, (Harvard Pub. Law Working Paper No. 13-23, 2013).

${ }^{6}$ Antonin Scalia, Originalism: The Lesser Evil, 57 U. CIN. L. REV. 849 (1988-1989).

7 RONALD DWORKIN, LAW's EMPIRE (1986).

8 Oliver Wendell Holmes, Montesquieu, in Collected Legal Papers 250, 258 (1920).

${ }^{9}$ Lawrence B. Solum, Constitutional Possibilities, 83 IND. L.J. 307 (2008).
} 


\section{Standard Theories}

Let me begin by examining standard theories of constitutional adjudication, originalism and Dworkinism, to see whether they can make any use of Beardian scholarship. ${ }^{10}$ I do not see how they can. Both originalist and Dworkinian judges show little interest in Beard, ${ }^{11}$ and given their theories that lack of interest makes perfect sense. Although the reasons differ somewhat in the two cases, the common theme is that neither the originalist nor the Dworkinian approach has any use for external debunking of the framers' motivations.

It is striking that originalists, who focus obsessively on the founding era, show so little interest in Beard. I believe there are several factors at work here. For one thing, originalism is a family of theories, and some members of the family are engaged in an enterprise to which Beard simply does not speak. To the extent that originalists emphasize the original public and semantic meaning of terms, Beard's work will be of little value to them. Originalists of that sort naturally look to the ratification debates, not to the confidential proceedings of the Philadelphia convention. Beard focuses precisely on those proceedings, and on the motivations of the framers who participated in them. By contrast, Beard's interest in the ratification debates is secondary, and not focused on original public meaning anyway. So Beard's potential relevance is largely restricted to older versions of originalism ${ }^{12}$ that look to the intentions of the framers at Philadelphia. But those versions have few adherents nowadays.

There is a deeper issue, however. Originalists of any stripe do not want to invoke an account of the founding era that casts an unflattering light on the motives of the political actors whose decisions are supposed, by the originalist theory, to be authoritative for later generations. This is a problem in the political theory of constitutionalism as much as a problem within constitutional theory in a narrower sense. The less normatively attractive the purposes and commitments of the framers, the harder it is to argue that their decisions should be seen as authoritative. The point is not a logical or jurisprudential one; I think we can imagine, although barely, a polity in which a constitution written by utterly self-interested actors is treated as binding law and interpreted along originalist lines. But from the standpoint of political psychology, a regime like that simply will not

\footnotetext{
${ }^{10}$ The recent fashion is for Dworkinians to call themselves originalists, see, e.g., JACK M. BALKIN, LIVING ORIGINALISM (2011), but nothing of substance in my discussion changes if we move the labels around in this way.

${ }^{11}$ In this setting, we should put very little stock in citation analysis of Supreme Court opinions; citation of any secondary non-legal materials by the Court was rare before about 1980. See Frederick Schauer \& Virginia Wise, Nonlegal Information and the Delegalization of Law, 29 J. LEG. STUD. 495 (2000). Home Bldg. \& Loan Ass'n v. Blaisdell, 290 U.S. 398, 421 n.3 (1934); see also GORDON S. WOOD, THE CREATION OF THE AMERICAN REPUBLIC, 1776-1787 (1969). For the little it is worth, however, I report that (1) Beard's book has been cited for the truth of its main thesis exactly once in an opinion by a justice of the Supreme Court, and even that was in a dissent - Justice Sutherland's dissent for the Four Horsemen in Blaisdell, (with friends like this, who needs enemies?); (2) by contrast, Wood's THE CREATION OF THE AMERICAN REPUBLIC, 1776-1787 has been cited twelve times by the Court, despite having been published nearly sixty years after Beard's book.

${ }^{12}$ RAOUl BERGER, GOVERNMENT By Judiciary (1977).
} 
fly. It is not psychologically possible to generate large-scale working commitment constitutional faith ${ }^{13}$ - in the service of a regime whose genesis is normatively disreputable, and known by all to be so.

Dworkinians also want an account of the Constitution that puts it in the best possible light, emphasizing justification in terms of political morality as well as fit with the legal materials; hence Beard's debunking emphasis on the self-interested motives of the framers and their constituents is difficult to incorporate into a Dworkinian framework. Fit and justification work at cross-purposes when the judge has to fit doctrine to a constitutional framework written to protect the class interests of property-holding merchant elites of the eastern seaboard, striking a corrupt bargain with southern slaveowners. Dworkinians, of course, are not limited to originalist sources or datapoints; when engaged in justification, the Dworkinian judge may draw "principles" from the entirety of political history, and this is both the main strength and main weakness of Dworkinism. But the constraint of fit means that the Dworkinian judge is supposed to connect current principles with the founding era in some sort of coherent chain-novel account. ${ }^{14}$ If the first chapter is hopelessly disreputable from a normative point of view, the chain-novel lacks integrity and never gets underway.

True, Dworkinian judges tend to emphasize the Reconstruction Amendments, with their guarantees of equality in various forms, and downplay the Constitution of 1787 to some degree. The Reconstruction Amendments are plausibly a more idealistic set of texts - although a standard debunking account explains their genesis in terms of the partisan interests of congressional Republicans. But in any event, the Reconstruction Amendments do not a Constitution make, not by themselves. They presuppose the basic structure of government set out in the document of 1787, and if the genesis of that structure is hopelessly disreputable, the Reconstruction Amendments fall too.

There are several ways to massage the problem, but none is fully satisfactory. One may observe that - according both to Beard and to the follow-on scholarship, like McGuire -- many of the framers, much of the time, weren't so much self-interested as faithful representatives of self-interested constituents, whose economic interests the framer-representatives understood particularly clearly. ${ }^{15}$ While that might or might not absolve the framers of personal opprobrium, depending upon what theory of representation one holds, it doesn't make the genesis of the Constitution any more normatively appealing. The framers' faithful agency on behalf of self-interested constituents would just add one more step in the chain of transmission between the normatively disreputable motives and the constitutional outcome.

\footnotetext{
13 SANFORD LeVinson, CONSTITUTIONAL FAith (2011).

14 DWORKIN, supra note 7, at 228-38.

15 Jon Elster, Securities Against Misrule: Juries, Assemblies, Elections (2013). In fact, Beard's text is systematically ambiguous as between this interpretation, and the cruder interpretation of direct selfinterest on the framers' own part. See Forrest McDonald, Introduction to CHARLES A. BEARD, AN ECONOMIC INTERPRETATION OF THE U.S. CONSTITUTION (The Free Press modern reprt. 1986)(1913). The famous protracted analysis of the framers' personal holdings of securities, BEARD, supra note * at 74-151, is relevant only if the claim is direct self-interest.
} 
For the same reasons, there is little comfort in the observation, true though it seems to be, that the main force operating on the framers was not self-interested motivation per se, but motivated reasoning, ${ }^{16}$ or self-serving beliefs about where the public interest lay ${ }^{17}$ - what Bentham would later call interest-begotten prejudice. ${ }^{18}$ If our concern is to allocate moral praise or blame to individuals, then we might care to know whether a representative purporting to serve the public interest is behaving selfishly because of a corrupt heart, or instead because of a biased head; perhaps the latter is less blameworthy, although even that is hardly clear. But if our concern is to understand whether the constitution under which we live and that the judges have to interpret has a normatively disreputable genesis, then it is hard to see why the distinction should matter at all.

Another approach - the most promising of the possible salvage operations - is to distinguish the framers' motives from their justifications. However disreputable the motivations for the constitutional rules they wrote, their rhetoric was public-regarding, and the judge may take them at face value, holding them to their professed ideals ("the civilizing force of hypocrisy,"19 enforced by judicial decree). To some degree, this is what originalists and Dworkinians actually do; when they quote the framers, it is invariably for some public-regarding justification of constitutional rules. Dynamically, constitutional law may be understood to work itself pure over time, through a kind of common-law process in which constitutional ideals and principles are progressively clarified and separated from the dross of the Constitution's self-interested origins.

Yet there are lingering problems here as well. One of the reasons that Beard's book retains the power to shock, even today, is that he so effectively compiles public statements by the framers that aren't particularly public-regarding at all, even at the level of ideals. Rather they reek of class interest or of the unselfconscious, but revealing, blinkered prejudices of a comfortable elite. Furthermore, public-regarding values change over time; Dworkinians in particular do not want to enforce professions of loyalty to values that are radically out of step with current political morality. And, finally, even if the framers say something that does count as public-regarding, and even if it still comports with current political morality, there is the problem of rationalization. Why exactly is it a good idea to seriously consider and enforce even public-regarding justifications for a rule $\mathrm{R}$, when if the rule had been $-\mathrm{R}$, there would inevitably have been a different, opposite, equally public-regarding justification for that? Of course the relevant justification might still be true, but the issue is whether the endorsement by a self-interested framer gives it any additional epistemic warrant or credence. The answer is no; we ought not have any greater confidence in the justification if we think that the

\footnotetext{
16 See Milton Lodge \& Charles Taber, Three Steps Toward a Theory of Motivated Political Reasoning, in ELEMENTS OF REASON, COGNITION, ChOICE AND BOUNDS OF RATIONALITY (2000).

${ }^{17}$ BEARD, supra note *.

${ }^{18}$ Jeremy Bentham, Bentham's Handbook of Political Fallacies, 54-56 (Harold A. Larrabee ed., 1954)(1824).

19 Jon Elster, Introduction, in DELIBERATIVE DEMOCRACY 12 (Jon Elster, ed., 1998).
} 
self-interested framer would have come up with some plausible justification for whatever rule happened to promote his interests.

These are not normative claims. They are conditional claims about the relevance of Beardian scholarship - conditional, that is, on accepting either originalist or Dworkinian premises. Neither approach can connect external Beardian scholarship with the internal project of constitutional adjudication. There is just no use, on the standard theories, for work that engages in systematic debunking of the framers' political motivations from an external point of view.

The consequence of all this is a radical disconnect between the discipline of constitutional history, on the one hand, and constitutional law on the other. Beard's work structured the whole field of constitutional history - whether through agreement or criticism - for two generations, and initiated a broader style of pitiless political explanation of the causal origins of constitutional arrangements. But constitutional law has been largely impervious to these sorts of external explanations.

Now this disconnect might not bother or puzzle us. We might be happy to have separate spheres of constitutional discourse, one external and one internal. In my view, however, knowledge about the disreputable causal origins of the constitutional rules creates a kind of shadow of illegitimacy that hangs over the internal legal enterprise. For those who think that causal origins are irrelevant to the internal legal enterprise, what if we discovered heretofore super-secret notes of the Philadelphia convention proving, indisputably, that as an elaborate joke the framers had rolled dice in a back room to determine what rules they would vote to adopt, and then (laughing up their sleeves all the while) staged apparently serious debates, complete with public-regarding justifications for those rules - could the internal enterprise of constitutional argument go on as before?

If we do find the disconnect between external and internal perspectives puzzling; if we would like some sort of coherence between our best positive accounts of constitutional lawmaking, and our normative accounts of constitutional lawmaking; if we want some sort of relationship between a major stream of constitutional research in history and political science, on the one hand, and constitutional adjudication on the other; then we need to consider the Holmesian approach to constitutional adjudication, to which I will now turn.

\section{Holmesian Adjudication}

Why, if at all, should judges deciding public-law cases care that the framers and their constituents acted, in important respects, on self-interested economic motives? Of course Beardian scholarship might have all sorts of utility other than for judges -- either intellectual utility for analysts of the constitutional system, or pragmatic utility for nonjudicial actors within the constitutional system. But my topic here will be its possible value for judging in public law, including constitutional law, administrative law, and statutory interpretation. 
I will suggest that Beardian scholarship may be connected up with the internal standpoint of legal actors through a Holmesian account of constitutional adjudication. The critical connection is that Holmes offers a nonideal theory of judging under political constraints, and Beardian scholarship serves the function of helping the judge to identify the political constraints correctly. Beardian scholarship, in other words, offers an expert assessment on a background question of legislative fact - namely, the shape and force of the political constraints that a nonideal theory of adjudication takes into account. Holmes believes that in judging, anyway, "ought implies can"; that "can" is shaped by politics as well as legal, technical and economic factors; and that the best course of action for judges to follow involves efficient compliance with political constraints, at least in the short run.

\section{A. The Least-Cost Principle}

Let me begin with a sketch of Holmes' view, which continues to be misunderstood despite all the ink that has been spilled. Holmes' thinking about law and politics was influenced by an unlikely pair of arguments, which really boil down to the same argument. One was a brilliant mini-essay by Montesquieu in the Persian Letters, in which Montesquieu puts into the mouth of one of his characters an apercu about government that struck Holmes as profound: "the most perfect [government] is that which attains its goal with the least friction; thus that government is most perfect which leads men along paths most agreeable to their interests and inclinations." In an essay on Montesquieu, Holmes characteristically paraphrased this idea in a more economic and subtly darker tone:

$[\mathrm{T}]$ he most perfect government is that which attains its ends with the least cost, so that the one which leads men in the way most according to their inclination is best. . . . What proximate test of excellence can be found except correspondence to the actual equilibrium of force in the community - that is, conformity to the wishes of the dominant power? Of course, such conformity may lead to destruction, and it is desirable that the dominant power should be wise. But wise or not, the proximate test of a good government is that the dominant power has its way. $^{20}$

The second argument was offered by the greatest mind law students have never heard of, James Fitzjames Stephen, the English barrister, judge and intellectual who is known today, if at all, largely for his withering critique of Mill. ${ }^{21}$ Stephen has many other major contributions and one is an important normative but nonideal account of politics, formulated in the mid- $19^{\text {th }}$ century when British intellectual elites had to grapple with the increasing democratization of British politics, and the increasing dominance of mass popular majorities. As to the dominance of the masses, Stephen observed that "there is no use in discussing the question whether this is a good state of things or a bad one. For all practical purposes it is enough to say that it exists, and that it is the part of rational men to make the best of it, as they make the best of the climate, the soil, or the national character

\footnotetext{
${ }^{20}$ HOLMES supra note 8, at 257-58.

${ }^{21}$ Sir JAMES FitZJAMES STEPHEN, LiBERTy, EQUALity, FrATERNITY, 1829-1894 (1873).
} 
of their country." 22 Rational political statesmanship, on the part of elites, takes the dominance of the masses as a political constraint and then looks for the best feasible course of action, given that constraint.

The unholy offspring of Montesquieu and Stephen is a principle that informs all of Holmes's work. We might call it the least-cost principle: political statesmanship consists in choosing the course of action that, at lowest possible cost, adjusts policy to match the "actual equilibrium of force in the community - that is, conformity to the wishes of the dominant power[]." 23 The adjustment should take place with a minimum of friction. There may be a minor role for statesmanship in slowing down the process of adjustment; Holmes once wrote in a casenote in the Harvard Law Review that "[a]ll that can be expected from modern improvements is that legislation should easily and quickly, yet not too quickly, modify itself in accordance with the will of the de facto supreme power in the community, and that the spread of an educated sympathy should reduce the sacrifice of minorities to a minimum." ${ }^{24}$ Another margin of discretion for elites arises because the dominant power -- dominant public opinion, in a democratic polity -- will have no well-formed views on many issues that lack political salience, or that are technically complex. There may also be issues as to which the views of the dominant power are partially endogenous, susceptible to shaping by elites or statesmen; I return to this point later. But the overall idea, as to salient public questions on which dominant public opinion has a clear and firm view, is that the role of the statesman is to discern the actual equilibrium of force in the community, to adjust or update obsolete rules to conform to the wishes of the dominant power, and to execute the function that Marx attributed to the vanguard - to "shorten and lessen the birth-pangs" 25 of transition to an impending state of economic and political relationships, and their inevitable embodiment in law.

The cold logic of the least-cost principle does not rest on a directly normative or ideal account of political morality. Instead it rests on an indirectly normative or nonideal account of political morality. The cold logic is that the dominant political forces will have their way in any event, sooner or later. The only feasible choices are to give them what they want after a costly struggle, creating deadweight social losses, or to give them what they want sooner rather than later, at lower cost and with less friction.

An illustration is the Reform Bill of 1867, by which Disraeli expanded the franchise after massive demonstrations. Stephen thought this was enlightened statesmanship, despite his pessimism about the policies that a mass democratic society would produce. It was enlightened because the alternative was an even costlier bout of civic turmoil, which would have eventually produced the same broader distribution of political power anyway, just at higher cost. "[The Reform Bill of 1867] was passed because it was felt universally that some such measure was necessary in order to adjust

22 SiR James FitzJames StePhen, Parliamentary Government I, 23 The CONTEMP. ReV., 1, 1 (1874).

${ }^{23}$ HOLMES supra note 8.

24 Anonymous [Oliver Wendell Holmes, Jr.], The Gas-Stokers'Strike, 7 AM. L. REV. 582 (1873).

${ }^{25}$ Karl MarX, Preface to CAPITAL: A CRitiQue of Political ECONOMY, 15 (Samuel Moore \& Edward Aveling trans., 1906). 
the form of our Government to the great changes which had taken place in the body of the nation. In short, a step was taken with a good grace which it would have been absolutely necessary to take somehow or other, sooner or later." ${ }^{26}$

Holmes picked up this least-cost principle and transposed it into an account of adjudication on the American scene. In criminal law, Stephen had famously written that "[t]he criminal law stands to the passion of revenge in much the same relation as marriage to the sexual appetite." 27 The state supplies regulated retribution and regulated reproduction because the unregulated versions of those activities will inevitably occur in any event, just in an unruly and more costly manner. Holmes made the political logic explicit, writing in The Common Law that "[t]he first requirement of a sound body of law is, that it should correspond with the actual feelings and demands of the community, whether right or wrong. If people would gratify the passion of revenge outside of the law, if the law would not help them, the law has no choice but to satisfy the craving itself, and thus avoid the greater evil of private retribution.",28

Likewise for constitutional adjudication. The function of constitutional adjudication is to ensure that "legislation should easily and quickly, yet not too quickly, modify itself in accordance with the will of the de facto supreme power in the community." ${ }^{29}$ Such an approach ensures that constitutional law will yield incentivecompatible constitutional rules and will thus embody a stable political equilibrium - until either the views of the dominant power change, or until the dominant power itself changes. Any other approach will produce pointless political friction, without changing the ultimate outcomes.

The least cost-approach underlies Holmes' most famous pronouncements about constitutional law. The point of the Lochner dissent was not to support progressive economic regulation, but to counsel other judges against a costly attempt - which would inevitably be futile in the long run - to deploy constitutional law so as to "prevent the natural outcome of a dominant opinion." 30 Although Progressives and New Dealers wanted to claim Holmes as a forerunner, he believed and said quite clearly that he thought Progressive economic and social policy was based on a sort of fiscal illusion. ${ }^{31}$ But he thought - like Stephen -- that the masses swayed by the illusion were firmly in the saddle, and that the only rational course of action for judges was to get out of the way.

So too for free speech. Holmes' dissent in Gitlow v. New York ${ }^{32}$, in my view, is far more characteristic of his overall approach than is his more famous dissent in Abrams

\footnotetext{
26 STEPHEN, supra note 22, at 4.

27 James FitzJames StePhen, General VieW OF THE CRIMINAL LAW OF ENGLAND 99 (1863).

28 Oliver Wendell Holmes, The COMMON LAW 4 (1881).

${ }^{29}$ HOLMES, supra note 24, at 583.

30 Lochner v. New York, 198 U.S. 45, 76 (1905) (Holmes, J., dissenting).

${ }^{31}$ HOLMES supra note 8, Economic Elements at 279.

32 Gitlow v. New York, 268 U.S. 652 (1925).
} 
v. United States (with its praise for "free trade in ideas") ${ }^{33}$. In Gitlow the majority upheld a conviction for distributing a socialist manifesto. Holmes' dissent argued, in effect, that the majority here was behaving just like the majority in Lochner, by attempting to use law to suppress what might turn out to be the politically dominant forces of the future. As Holmes put it, "[i]f in the long run the beliefs expressed in proletarian dictatorship are destined to be accepted by the dominant forces of the community, the only meaning of free speech is that they should be given their chance and have their way." 34

This is slightly counterintuitive, because the natural - although erroneous assumption is that the Holmesian approach would always counsel upholding government action, implying a dissent in Lochner but a vote with the majority in Gitlow. But because of the agency slack that may exist even in a democratic society, any given policy of the existing government may be out of step with the wishes of the dominant political power, and it is even more likely that the existing government will be out of step with a rising political power, such as the left-wing agitators in Gitlow. In my view Holmes's famous flip-flop on free speech, around the end of World War I, was at least partly due to a simple realization that the least-cost principle might sometimes underwrite constitutional protection, constitutional invalidation of current policies, where political speech was at issue. If socialism is "destined" to arrive, then allowing governmental repression of its advocates is an exercise in futility that raises costs all around, without changing the ultimate political outcome. Holmes was emphatically what we would today call a "living constitutionalist," although without the Whig optimism and progressive self-conception that tends to characterize the living constitutionalists. The whole tenor and spirit of Holmes' approach is elitist, pessimistic and Stephen-esque; the deep picture is that mass democratization is sending everything to hell, and that the politically realistic and economically-minded judge has no choice but to help his fellow-citizens get there at the lowest possible cost. ${ }^{35}$

For present purposes I need not defend Holmes' account of constitutional adjudication on the merits. The major objections to the account are tolerably obvious. One is that it might be worthwhile to delay a bad future even if we cannot, in the end, prevent it from coming into existence. Discounting applies to future costs as well as future benefits; a pain tomorrow is not as bad as a pain today. If some "rough beast, its hour come round at last, slouches towards Bethlehem to be born," terrible mistake to shorten and lessen the birthpangs.

Another objection is that the least-cost principle is excessively static. It assumes that the preferences and beliefs of the dominant coalition are strictly exogenous to law;

\footnotetext{
33 Abrams v. U.S., 250 U.S. 616, 630 (1919) (Holmes, J., dissenting).

${ }^{34}$ Gitlow, 673 (Holmes, J., dissenting).

35 As indeed Holmes famously said: "I always say, as you know, that if my fellow citizens want to go to Hell I will help them. It's my job." Letter from Oliver Wendell Holmes to Harold J. Laski (Mar. 4, 1920) in 1 Holmes-LASKi LetTERS: THE CORRESPONDENCE OF Mr. Justice HolmeS AND HAROLD J. LASKi, 19161925, at 249 (Mark DeWolfe Howe ed.,1953).

36 W.B. Yeats, The Second Coming, in The Collected Poems of W.B. Yeats 185 (definitive ed. 1956)(1919).
} 
thus Holmes assumes in Gitlow that socialism either is, or is not, "destined" to arrive. But there is a dynamic possibility that the political constraints may be partly endogenous, at least in the long run. Constitutional adjudication might itself help to shape the preferences and beliefs of political actors, at least in part. To the extent that the causal arrow sometimes runs from constitutional law to political preferences and beliefs, not just the other way round, then the least-cost principle might actually be politically naïve, despite its hard-headed appeal. Put conversely, the Holmesian approach must assume that the judge is capable only of imposing the costs of friction, and is incapable of actually changing the inevitable course of events.

Finally, the Holmesian judge labors under the severe informational burden of discerning where, exactly, the "actual equilibrium of force in the community lies," or even worse where it may lie tomorrow. In addition to the usual legal sources, the Holmesian judges takes on the incremental burden of understanding the history, current state and future direction of constitutional politics. Yet Beardian scholarship may be able to help; I will return to these crucial issues shortly.

What matters for present purposes is just that Holmes offers a distinctly nonideal account of constitutional adjudication, one that takes into account both current political constraints and impending changes in the distribution of political power, and that shapes legal rules accordingly. Because it is nonideal, Holmes' account connects up "ought" and "can" in a certain way; ought implies can, which means that cannot implies ought not. If a certain decision is infeasible, there is no obligation to undertake it. This connects the external and internal perspectives on the constitutional enterprise; external analysis may help to identify the political constraints and forces that must be taken into account by the nonideal statesmanship of judges and others actors internal to the system. That feature creates space for Beardian scholarship.

\section{B. The Beardian Contribution}

Holmes thought rather poorly of Beard's book. To Beard himself, he said something that was truthful, polite, but reserved: that the book "was intended to throw light on the nature of the Constitution, and, in [Holmes's] opinion, did so in fact." ${ }^{, 37}$ In correspondence with Sir Frederick Pollock and Harold Laski, however, Holmes called the book "a covert sneer" at the framers' motives and "rather ignoble." 38 Characteristically, Holmes seems to have felt the book, even if true, to be a bit churlish, even ungentlemanly.

Yet I believe that Holmes here misunderstood the implications of his own view; he ought to have been more Beardian than he was. In the Holmesian framework, the function of Beardian scholarship is to help judges identify the preferences and beliefs of the constitutionally dominant coalition. The Beardian scholar serves as an expert witness about constitutional politics. The Beardian need not violate the professional historian's

\footnotetext{
${ }^{37}$ Quoted in Richard Hofstadter, The Progressive Historians: TURner, BeARd, PARrington, 212 (1968).

${ }^{38} I d$.
} 
reluctance, or the political scientist's reluctance, to draw normative conclusions from their explanatory work. Rather the Holmesian judge takes the explanatory input as evidence of the shape of the political constraints and, by the alchemy of the least-cost principle, transforms it into an indirect, nonideal normative conclusion.

There is a slippage here, between history and current political science. The slippage is that the Holmesian judge is not interested in history for its own sake, but in history as evidence of current or near-future political equilibria. History might supply evidence about what the dominant political coalitions once were, and might even identify repeated patterns of regime-change or transition, as in the historically-inflected work on the typology of presidential regimes and the dynamics of transition between presidential regimes. ${ }^{39}$ Yet depending on the issue, the Holmesian judge might well prefer current evidence about dominant political coalitions, supplied by political scientists, journalists and watchers of politics, or even opinion polls. ${ }^{40}$ Even when Holmes was writing, Beard's own work offered the Holmesian judge a rapidly depreciating asset, because the founding era was politically ever more remote and the relevant coalitions largely a thing of the past. That is true a fortiori today. (So perhaps Holmes was right after all about Beard's book, insofar as it held little use for him - although that was not the ground on which he disparaged it).

Yet I do not at all think that the near-irrelevance of Beard's own book to the Holmesian judge makes Beardian scholarship irrelevant to the Holmesian judge. We have to distinguish Beard from the Beardian tradition and style of scholarship, just as we have to distinguish Madison from the Madisonian tradition and style of constitutional theory. The significance of Beard's book is not direct, as evidence for current judges about the shape and force of current political constraints; the founding era is too remote for that. Rather the significance of the book is indirect, which does not mean unimportant. What Beard did was to shatter a spell or break a taboo. Before Beard external history of the constitution was overwhelmingly celebratory. After Beard, although historians went back and forth over the generations about the substantive merits of Beard's thesis, it was always professionally permissible to offer an external explanation of the behavior of constitutional actors as a product of their preferences, beliefs and political opportunities. Beard's book initiated a broader tradition, spirit and outlook of economic and political realism about constitutional rulemaking.

Beardian scholarship will thus contribute external analysis and explanation that will, on the Holmesian approach, be directly relevant to the internal but nonideal standpoint of the constitutional judge. Under the maxim "ought implies can," the

\footnotetext{
${ }^{39}$ Steven Skowronek, The Conservative Insurgency and Presidential Power: A Developmental Perspective on the Unitary Executive, 122 HARV. L. REV. 2070 (2008-2009).

40 The potential relevance of opinion polls to the Holmesian judge is amusingly satirized in Lon L. Fuller, Case of the Speluncean Explorers, 62 HARV. L. REV. 616 (1949); the Holmesian figure is Judge Handy, who bases his decision on shaky evidence of public opinion because he believes that men "are ruled well when their rulers understand the feelings and conceptions of the masses." 638. $C f$. Holmes's "first requirement of a sound body of law ... that it should correspond with the actual feelings and demands of the community, whether right or wrong." HOLMES, supra note 28, at 41.
} 
Holmesian approach ties the normative theory of constitutional adjudication to political constraints and incentives. Beardian scholarship helps judges to identify those constraints and incentives.

To give only one recently topical example, work at the intersection of law, history and political science suggests that there is a "New Deal settlement" 41 that places certain constitutional possibilities out of bounds for judges. In the abstract, judges with libertarian and decentralizing sympathies might be persuaded that the constitutional sources prohibit federal laws against interstate shipment of goods produced with child labor; we know they might be so persuaded because once upon a time, they were. ${ }^{42}$ The constitutional text is simply indeterminate on this score. Yet we can be utterly confident, in light of the New Deal settlement, that today's libertarian and decentralizing judges could not get away with a ruling like that, even if they wanted to do so. Holmes's leastcost principle adds that respecting the boundaries of the New Deal settlement is good statesmanship and hence good constitutional judging, because doing so corresponds to the actual equilibrium of political force in the community.

Again, nothing here is intended as a defense of the joint Beardian-cum-Holmesian approach on the merits, as opposed to other approaches to constitutional adjudication. The role of Beardian scholarship as a sort of expert evidence on the shape and force of political constraints sharply poses the questions about judicial competence and information costs that I briefly adverted to earlier. Scholarship about constitutional politics being what it is, there may well be dueling Beardian experts who differ because of intractable, reasonable, good-faith disagreement about what the evidence shows. Even worse, scholarship about constitutional politics being what it is, there may well be a duel between one true expert and one false "expert," bought and paid for by a political coalition on one side of the issue; then the court is put to the test of sorting the false from the true. Finally, the marginal difficulty of adding evidence about public opinion and political constraints to the ordinary sources of constitutional decisionmaking may be very great. The nature of the relevant evidence is diffuse and varied, and legal training does not help the judge to evaluate the currents of public opinion. Holmes never did tell us how, exactly, to ensure that law "correspond[s] with the actual feelings and demands of the community, whether right or wrong.",43

Of course judges who purport to ignore public opinion may well actually be taking it into account sub rosa, in high-salience cases especially. The New Deal settlement, although fraying at the edges, retains power in its core; it is hard to explain Chief Justice Roberts' famous flinch - casting the decisive vote to uphold the crucial provisions of the Patient Protection and Affordable Care $\mathrm{Act}^{44}-$ except on the hypothesis

\footnotetext{
41 Lawrence B. Solum \& Larry Alexander, Popular? Constitutionalism?, 118 HARV. L. REV. 1594, 1599 (2005) (reviewing Larry D. Kramer, The People Themselves: Popular Constitutionalism and Judicial Review, 219-26 (2004)); see also Cass R. Sunstein, Constitutionalism After the New Deal, 101 HARV. L. REV. 421 (1987).

${ }^{42}$ Hammer v. Dagenhart, 27 U.S. 251, (1918).

${ }^{43}$ HOLMES, supra note 28.

${ }^{44}$ Nat'1 Fed'n of Indep. Bus. v. Sebelius, 132 S. Ct. 2566 (2012).
} 
that the Chief Justice was worried about a severe backlash and consequent retaliation, from the President, the Democratic Party, and sectors of the public, that would seriously damage the Court. ${ }^{45}$ In other words the Chief Justice acted as a Holmesian judgestatesman, bowing to political constraints and the unwritten constitutional norms of the New Deal regime. ${ }^{46}$ To the extent judges behave like that, there is a standard sort of candor argument for the Holmesian approach; it will happen anyway, so it is better to bring it all out into the open.

Whatever conclusion one reaches about all this, the main point is methodological. The joint Beardian-cum-Holmesian approach shows that the gulf between external and internal perspectives on constitutionalism is not unbridgeable. The two may in principle be connected up by a nonideal approach to judging that takes political constraints into account, as in the least-cost principle. A century ago, Beard set us a puzzle to which Holmes offered us one possible answer.

\footnotetext{
45 Jan Crawford, Roberts Switched Views to Uphold Health care Law, CBS News, (July 1, 2012), http:/www.cbsnews.com/8301-3460 162-57464549/roberts-switched-views-to-uphold-health-care-law/. But cf. Lawrence Solum, The Decision to Uphold the Mandate as Tax Represents A Gestalt Shift in Constitutional Law, 3 J.L. 173 (2013). An interesting contrast here are the Watergate-era cases in which the Court felt able to confront a (temporarily) weakened presidency. See, e.g., United States v. Nixon, 418 U.S. 683 (1974). In such cases latent political constraints on the Court, arising from the implicit threat of presidential retaliation, were temporarily relaxed. Thanks to Heidi Kitrosser for this point.

${ }_{46}$ Adrian Vermeule, Constitutional Conventions, New Republic (August 2, 2012), http://www.newrepublic.com/book/review/power-precedent-michael-gerhardt.
} 